\title{
IAMJ
}

INTERNATIONAL

AYURVEDIC

MEDICAL JOURNAL

Review Article

ISSN: 2320-5091

Impact Factor: 6.719

\section{CONCEPTUAL STUDY OF AROGYAVARDHINI VATI}

\author{
Vrushali Dipak Ghule ${ }^{1}$, Kavita Deshmukh², Kalyani Jadhav ${ }^{3}$ \\ ${ }^{1}$ PG Scholar, PG Department of Rasashatra and Bhaishajya Kalpana, \\ ${ }^{2}$ Guide, Department of Rasashatra and Bhaishajya Kalpana \\ ${ }^{3}$ HOD, Department of Rasashatra and Bhaishajya Kalpana
}

Corresponding Author: vrushalighule12@gmail.com

\section{https://doi.org/10.46607/iamj2809122021}

(Published Online: December 2021)

Open Access

(C) International Ayurvedic Medical Journal, India

Article Received: 28/11//2021 - Peer Reviewed: 02/12/2021 - Accepted for Publication 15/12/2021

\section{Check for updates}

\section{ABSTRACT}

Ayurveda is considered by many scholars to be the oldest healing science. In Sanskrit, Ayurveda means "The Science of Life". We are experiencing a renaissance of an ancient system of health promotion; disease prevention and treatment and this indigenous knowledge has transformative potential to heal mental and physical ailments but in maximum cases, there is a lack of data regarding their detailed mechanism of actions. The present study aims to compile all the information and literature regarding one of the classical formulations "Arogyavardhini Vati". It is official in the ayurvedic formulary of India and is safe and effective in hyperlipidaemia, ear discharge with its hepatoprotective and antioxidant activity. It is also used in jaundice, skin disorders, fevers, oedema, indigestion, and obesity. We will see the review of "Arogyavardhini Vati' in this article.

Keywords: Arogyavardhini, Kustha.

\section{INTRODUCTION}

Arogyavardhini Vati is great Rasayan, Pachani, Dipani ${ }^{1}$. Arogyavardhini Vati cures all Kushtha Roga after consuming it for 42 days. Relieves various types of fever. In Case of fever, the pill should be given on the sixth day ${ }^{2}$. It is also used in the treatment of
Jaundice and other liver and skin disorders ${ }^{3}$. It acts as an alternative, Carminative stomachic ${ }^{4}$. This Guti has been Created by Shri Nagarjuna Yogi Raja. His great ingenuity is evident in making it ${ }^{5}$. This Vati destroys the deformity of the large and small intestine. It 
provides digestive juices and strengthens the liver ${ }^{6}$. Therefore, it is beneficial in chronic indigestion and liver problems. It removes heart failure and reduces inflammation in the urinary tract. It is. beneficial in Mededosha due to and accelerating digestion power balancing of metals ${ }^{6}$. Arogyavardhini Vati is mentioned in "Rasratnasamucchay" for Kushtha ${ }^{7}$ and in "Bhaishajyaratnavali" for yakrit vikara. Literacy sources have been used in this study. All the related available in text and have been Collected. Rasa ${ }^{9}$ is tikta, katu. Virya ${ }^{9}$ is anushna shita. Vipak ${ }^{9}$ is bitter and has short, dry, expectorant, anti-indigestion juice, purifies blood vessels, flesh and fat, prevents excess growth, is an antiseptic, reduces urinary incontinence and pierces faeces.

\section{Materials and Method ${ }^{10}$ :}

Pure mercury and pure sulfur should be mixed in kharal yantra to make kajjali. Then add loha bhasma, Tamra bhasma and Abhrak bhasma in this kajjali in kharal yantra. Then add chitrak powder, kutki powder and triphala powder and mix well. Neem leaves should be washed and crushed with clean water; Add stock of water, strain the solution into a cloth and squeeze the juice; Let stand for an hour, then use juice from the surface. In this juice first, add pure guggul and pure shilajit and dissolve them. When it is well mixed, add all the ingredients mixed in kajalli in kharal yantra. Two bhavana of nimba leaves are given. After all the process Vati is made.

\section{Ingredients of Arogyavardhini with amount:}

\begin{tabular}{|c|c|c|c|}
\hline No. & Ingredients & Botanical Name & Amount \\
\hline 1. & Shuddha Parada (Herbal purified Mercury) & - & 1 part \\
\hline 2. & Shuddha Gandhaka (Herbal purified Sulphur) & - & 1 part \\
\hline 3. & Loha Bhasma (Ash prepared from Iron) & - & 1 part \\
\hline 4. & Abhraka Bhasma (Purified and processed Mica) & - & 1part \\
\hline 5. & Tamra Bhasma (Ash prepared from copper) & - & 1 part \\
\hline 6. & $\begin{array}{l}\text { Triphala } \\
\text { a. Haritaki- (Chebulic Myrobalan fruit rind) } \\
\text { b. Bibhitaki-(Belliric Myrobalan fruit rind) } \\
\text { c. Amalaki - (Indian gooseberry fruit) }\end{array}$ & $\begin{array}{l}\text { a. Terminalia chebula Retz. } \\
\text { b. Terminalia bellirica Roxb. } \\
\text { c. Emblica officinalis Gaertn. }\end{array}$ & 2 parts \\
\hline 7. & Shilajatu (Mineral pitch) & Asphaltum & 3 parts \\
\hline 8. & Pure-Guggulu-(Indian bedelium /gum resin) & Commiphora mukul Hook ex stocks & 4 parts \\
\hline 9. & Chitramool- (the root of Indian led word) & Plumbago zeylanica Linn. & 4 parts \\
\hline 10. & Tikta - Katuki & Picrorhiza kurroa Royle ex Benth. & 4 parts \\
\hline 11. & Juice extract of Nimba leaf - Neem & Azadirachta indica A. Juss & Quantity as per need \\
\hline
\end{tabular}

\section{Indication ${ }^{11}$ :}

- Kushtha - Its use in the early stage of leprosy gives quick benefits. In chronic leprosy, when the blood and flesh are contaminated, it turns into a pus-like form of leprosy; So, it does not benefit from this. Especially its use on Vata and Kapha predominant or Vata-Kapha predominant leprosies like Kapal, Mandal Vipadika, Charmdaladi and Alsak gives quick benefits. During the intake of this medicine, an equal quantity of milk should be consumed in the diet.
- Heart disease - Excessive accumulation of stool leads to Baddhakoshtha. Due to which there is an increase in Kapha dosha and it is also madagni. Then, due to the lack of proper digestion of food grains, aharrasa, rakta dhatu are also not produced in proper quantity. Therefore, instead of the increase of blood cells, only the water part of the body keeps on increasing. In such a condition, the heart becomes weak due to swelling in the whole body, due to which the heart becomes unable to do its work. In such times, giving Arogyavardhini Vati with Punarnavadi Kwath is very beneficial. 
- Constipation - Due to chronic constipation, the stool sticks in the intestine. The walls of the intestine become hard, as the stool becomes dry. Then there is a difference in the action of the intestines and pain also starts in it. This pain is not suppressed by simple churna etc. unless the stool is purified. Arogyavardhini Vati does this work well with Triphala Kwath. It melts and comes out and softness comes in the intestines, and it starts doing its work well.

Anupana 12: Water, milk, Punarnavadi Kwatha, Dashmula Kwatha, Mangishthadi kwatha, etc.

Matra ${ }^{13}$ : 2-4 ratti.

Side effects- Self-medication with this medicine is discouraged as it contains mercury as an ingredient. It should be taken for a limited period as advised by the doctor. Overdosage may cause serious poisonous effects.it should be strictly avoided in pregnant women, lactating women, and children.

\section{DISCUSSION $14,15,16$}

- Arogyavardhini Vati is one of the most effective Ayurvedic preparations which help to manage acne or pimples due to its Pitta and Kapha balancing, and Shothahara (anti-inflammatory) properties. It also helps in blood purification by removing toxins due to its Shodhan (detoxification) property

- Arogyavardhini Vati is an Ayurvedic preparation that helps to manage the condition of constipation due to its Vata balancing and Rechan (laxative) properties

- Arogyavardhini Vati is an effective Ayurvedic preparation that helps to reduce weight by reducing Ama due to its Deepan (appetizer) and Pachana (digestion) properties. It also helps to eliminate the waste product from the body because of its Shodhan (detoxification) nature

- Arogyavardhini Vati is one of the most effective Ayurvedic preparations which is used in the management of anorexia due to its Tridoshahar (balancing Vata, Pitta, and Kapha) properties. It improves digestion due to its Deepan (appetizer) and Pachan (digestion) properties
- Arogyavardhini Vati helps manage irritable bowel syndrome as it aids in the digestion of Ama. It further helps to control mucus in the motion and the urge of frequent passing of stool due to its Deepan (appetizer) and Pachana (digestion) properties

- Arogyavardhini Vati helps to manage anaemia due to its Tridosha (mainly Pitta) balancing property. It also helps to improve digestion because of Deepan (appetizer) and Pachana (digestion) properties, thus helping in minimizing the symptoms of Anemia.

- Action according to Rasa, Virya-Rasa-Katu, Tikta (Kledda, Meda, Majja shoshak. ViryaChitrak and Tamra have ushna virya which is balanced by Nimba patra swarasa which is the cause of action Dipana.

- Action on strotas- Annavaha strotas - Dipana, Pachan avoids Agnimandya and Strotoshodhan. Pranvaha stotas- Avoid strotoshodhan at the site of Heart and Lungs, also works on Udakvaha and Medavaha strotoshodhan.

- Main properties of constituent materials ${ }^{17}$ -

1. Paragandhak Kajjali - Krumighna, Rasayana, Yogavahi

2. Lohabhasma - Blood enhancer, anti-inflammatory, varna, balya,

3. Tamrabhasma - antitoxin, Blood thinner, liver stimulant and biliary.

4. Asbestos - Marrow enhancer, strength, rasayana.

5. Triphala - Kleda nashak, Diuretic, Fat Looser, rasayana, vranaropak

6. Guggul - Anti-decongestant, rasayana, anti-inflammatory.

7. Chitrak- Deepak, digestive, liver and duodenal stimulating, kushthghna.

8. Kutki- Bitter, piercing property, stimulating the liver, jwarghna.

9. Neem - It is bitter, cold, expectorant and anti-leprosy.

\section{CONCLUSION}

This Vati is made by Acharya Nagarjuna. It is mainly useful in Kushtha roga i.e known for 'Hantikushthanyasheshata'. It is Dipani, Pachani, Pathyakarak, 
Hrudya. It increases appetite, purifies the gut, helps to decrease fat etc. It especially works as Grahani sho$d h a k$, so it becomes useful in different types of fever related to Grahani. Arogyavardhini Vati improves overall good health by balancing all three Doshas. This drug must be consumed with various adjuvants for getting the desired effect. Self-medication of drugs should be strictly avoided to overcome any untoward effects.

\section{REFERENCES}

1. Tripathi Indradev. Rasaratna Samuchchaya. 20/86-92, 3rd ed., Varanasi; Chaukhambha Sanskrit Bhawan; 2006, p. No. -576.

2. Go. Aa. Fadke. Siddhaushadhi sangraha. Jan $-2013,6^{\text {th }}$ ed., Shivaji nagar, Pune. P. No. - 35 .

3. Kumar G, Srivastava A, Sharma SK, Gupta YK. Safety evaluation of Ayurvedic medicine, Arogyavardhini Vati on brain, liver and kidney in rats. J Ethnopharmacol. 2012; 140:151-60.

4. Anonyms. Rasatantrasara and Siddhayoga Sangraha. 1st edition. Ajmer, Rajasthan: Krishna Gopal Ayurveda Bhavana Publisher; 2015 p.150-153.

5. Sarashetti R.S., Simpi C.C., Sandeep N.M., Kanthi V. G. Screening of free radical scavenging activity of Arogyavardhini Vati. Int. J. Res. Ayurveda Pharm. 2013;4(4):555-559 http://dx.doi.org/10.7897/2277 4343.04421.

6. Shri. Baidyanath Ayurved Bhavan Pvt. Limited. Ayurved Sarsangraha. Aug - 2017, great nag road, Nagpur.p.No.- 259.

7. Ambikadatta shastri. Rasaratna Samuchchya. 9th edition. Chapter no-20. Verse no-87. Varanasi: Chaukhamba Sanskrit Publisher;1994. p. 400.

8. Kaviraj Govinda Das Sen. Bhaisajyaratnavali. Siddhipada Hindi Commentary, Prof. Siddhinandana Mishra editor. 1st edition. Kustharogadhikara, Chapter no-54, Verse no-117, Varanasi: Chaukhamba Surbharati Prakashana; 2012.p.871.

9. Go. Aa. Fadke. Siddhaushadhi sangraha. Jan $-2013,6^{\text {th }}$ ed., Shivaji Nagar, Pune. P. No. - 36.

10. Tripathi Indradev. Rasaratna Samuchchaya. 20/86-92, 3rd ed., Varanasi; Chaukhambha Sanskrit Bhawan; 2006, p. No. - 575.

11. Vaidya Panchanan Gangdharshatri Gune. Ayurvediya Aushadhi Gunadharmashastra. Chaukhambha sanskrit pratishtha. Delhi. P. No. -28 to 31 .
12. Arogyavardhini Vati Benefits, Uses, Dosage \& Side Effects, [Home page on the internet]. Downloaded on 12/09/2016. Available at- https://www.ayurtimes.com.

13. Shri. Baidyanath Ayurved Bhavan Pvt. Limited. Ayurved Sarsangraha. Aug - 2017, great nag road, Nagpur.p.No.- 259.

14. Shekhar Reddy P. Aushadhi Yoga Gyanam. A Textbook of Rasashastra. Chaukhambha Orientalia. 2017:448.

15. Pal S, Ramamurthy A and Mahajon B. Arogyavardhini Vati: A theoretical analysis. J Sci Innov Res 2016; 5(6): 225-227.

16. Kumar G, Srivastava A, Sharma SK, Gupta YK. Safety evaluation of Ayurvedic medicine, Arogyavardhini Vati on brain, liver and kidney in rats. J Ethnopharmacol. 2012 Mar 6;140(1):151-60.

17. Go. Aa. Fadke. Siddhaushadhi sangraha. Jan $-2013,6^{\text {th }}$ ed., Shivaji Nagar, Pune. P. No. -35 .

\section{Source of Support: Nil Conflict of Interest: None Declared}

How to cite this URL: Vrushali Dipak Ghule et al: Conceptual Study Of Arogyavardhini Vati. International Ayurvedic Medical Journal \{online\} 2021 \{cited December 2021\} Available from: http://www.iamj.in/posts/images/upload/3098_3101.pdf 